\title{
Feulgen-DNA content and chromatin organization in the spermathecal glands of Apis mellifera (Hymenoptera, Apoidea) queens with aging
}

\author{
Lara M. C. Peres ${ }^{1}$, José Ricardo P. Falco, ${ }^{1, *}$, Thaísa J. Aguirra ${ }^{1}$, \\ Maria Luiza S. Mello ${ }^{1}$ \\ ${ }^{1}$ Department of Structural and Functional Biology, Institute of Biology, University of Campinas, CEP 13083-862 \\ Campinas, SP, Brazil
}

Received 1 November 2013 - Revised 10 January 2014 - Accepted 5 February 2014

\begin{abstract}
The secretions from the spermathecal glands in honeybee queens contribute to maintaining the viability of spermatozoa stored in the spermatheca. This viability is reduced as the queen ages. Here, we investigated whether DNA content changes and chromatin remodeling, that could suggest changes in cellular functions, occur in the spermathecal glands of Apis mellifera queens with aging. Feulgen-stained glands from early-mated and old queens were studied by image analysis. Increased polyploidization, heterogeneously distributed chromatin coarseness, and no cell death signs were verified in the spermathecal glands of aged queens. These results, compared with published data for other cellular systems, are suggestive of alterations in the spermathecal gland cells upon aging, possibly affecting their secretory fluid production. In consequence, sperm cell protection in the spermatheca would be less effective.
\end{abstract}

queen / spermathecal glands / polyploidy / chromatin / aging

\section{INTRODUCTION}

Soon after a honeybee queen is either naturally or artificially inseminated, the spermatozoa introduced in her reproductive system migrate to the spermatheca, where they can potentially be stored over along the queen's entire lifespan (Verma 1974; Al-Lawati et al. 2009). When performing an oviposition task, the queens have the ability to lay down sperm-fertilized diploid eggs, which will result in females (workers or queens), as

Corresponding author: M.L.S. Mello, mlsmello@unicamp.br

Manuscript Editor: Klaus Hartfelder

*Current address: Department of Biotechnology, Genetics and Cell Biology, State University of Maringá, CEP

87020-900 Maringá, PR, Brazil well as unfertilized haploid eggs, that will give rise to drones.

The sperm cells stored in the spermatheca are nourished and protected from oxidative stress and activated by a secretion produced in the spermathecal glands (Laidlaw 1944; Camargo and Mello 1970; Verma 1974; Weirich et al. 2002; Klenk et al. 2004; den Boer et al. 2009). The spermathecal glands are a pair of long and convoluted structures, consisting of a single secretory epithelium and an intima layer, and are located over the latero-anterior surface of the spermatheca. These glands unite into a common duct, which opens on the antero-ventral midline of the organ (Camargo and Mello 1970). The intima nuclei are positioned laterally to each canaliculum, which collects the glandular secretion intracytoplasmically from each secretory epithelial cell and passes it to the glandular lumen (Camargo and Mello 1970). 
The spermathecal glands are the main source of the proteins found in the spermathecal fluid, as the epithelium of the spermatheca lacks glandular structures (Dallai 1975; Klenk et al. 2004; den Boer et al. 2009). The protein profiles of the spermathecal gland secretion and the spermathecal fluid are very similar to each other, except for an additional $79 \mathrm{kDa}$ protein in the gland secretion and a $29 \mathrm{kDa}$ protein in the spermathecal fluid (Klenk et al. 2004). Although secretions from the queen's spermathecal glands provide an important beneficial function for the stored spermatozoa, facilitating their survival (den Boer et al. 2009), the viability of these cells is affected as the queens age (Al-Lawati et al. 2009). It is also known that mated queens tend to lay an increased number of unfertilized eggs as they age (Szabo and Heikel 1987), which could be due to the decreasing quality of the stored spermatozoa caused by their inadequate preservation.

A decline in the amount of Feulgen-stained DNA with increased age, possibly promoted by DNA fragmentation and/or a decrease in DNA repair has been reported for the Malpighian tubules of the blood-sucking insect Triatoma infestans (Mello and Raymundo 1977). Chromatin remodeling estimated by image analysis parameters (chromatin entropy, for instance) has been described in aging mouse liver and neurons in association with changes in their gene expression (Ghiraldini et al. 2012, 2014; Rodrigues et al. 2014). Significant changes in several chromatin image features have been determined with image analysis in neurons and Malpighian tubule cells of the aging housefly (Panno and Nair 1984). However, no data on changes in DNA content and chromatin supraorganization have been reported for spermathecal glands in aged queens that could be associated with changes in the physiology of these organs, potentially interfering with the production of a fluid that should be adequate for maintaining the viability of the stored sperm.

The objective of this work was to detect changes in the amounts of Feulgen-stained DNA and in chromatin supraorganization in the spermathecal glands of Apis mellifera queens as they aged, in an effort to understand the decrease in their cell functionality and to support the idea that, due to aging, the protection provided to the sperm in the spermatheca by the secretory fluid produced by the spermathecal glands is reduced.

\section{MATERIALS AND METHODS}

\subsection{Materials}

Early-mated and $~ 1.5$-year old egg-laying queens of African-derived A. mellifera Linnaeus were obtained from laboratories at the University of São Paulo at Ribeirão Preto (SP, Brazil) (21 ${ }^{\circ} 10^{\prime} 7^{\prime \prime} \mathrm{S}$ and $47^{\circ} 51^{\prime}$ $37^{\prime}$ W) and the State University of São Paulo at Rio Claro (São Paulo state, Brazil) $\left(22^{\circ} 23^{\prime} 47^{\prime}\right.$ 'S and $47^{\circ}$ 32 ' $49^{\prime \prime} \mathrm{W}$ ). Three to five specimens from each location were tested. Early-mated and one-year old egg-laying queens (three of each) purchased from local beekeepers at Faria Lemos (Minas Gerais state, Brazil) (20 $47^{\circ}$ $22.20^{\prime \prime} \mathrm{S}$ and $42^{\circ} 5,38.82^{\prime}$ ' W) were also examined for comparative purposes. Although there are reports of honeybee queens living up to five years (Butler 1954), the 1.5-year age used here has been considered to be an indicator of aging processes in queens; indeed, this age is considered the mean longevity for queen honeybees used for beekeeping purposes in Brazil (Warwick E. Kerr, 1968-personal communication, apud Camargo and Mello 1970). In tropical American regions, it has been recommended that honeybee colonies be requeened every $6-9$ months, as less than $28.1 \%$ out of the inseminated queens have been found to remain in their hives more than 12 months after being introduced into a colony (Guzman-Novoa et al. 1998).

The bees were dissected in Ringer's saline solution for insects, and their spermatheca and spermathecal glands were fixed in absolute ethanol-glacial acetic acid $(3: 1, v / v)$ for $1 \mathrm{~min}$, rinsed in $70 \%$ ethanol for $5 \mathrm{~min}$ and stored in $70 \%$ ethanol at $4{ }^{\circ} \mathrm{C}$ until use.

\subsection{Cytochemistry}

The organs were subjected en bloc to the Feulgen reaction, a cytochemical method specific for DNA (Mello 1997), preceded by treatment with a $5 \%$ sodium borohydride aqueous solution and an acetone-chloroform solution $(1: 1, v / v)$, for $15 \mathrm{~min}$ each, to prevent any non-specific Feulgen-positive 
response (plasmal reaction), as previously detected in bee tissues (Mampumbu et al. 2004). The acid hydrolysis step of the Feulgen reaction was performed in $4 \mathrm{M} \mathrm{HCl}$ for $80 \mathrm{~min}$ at $25{ }^{\circ} \mathrm{C}$. The hydrolysis reaction was quenched by rapid treatment with cold $0.1 \mathrm{M} \mathrm{HCl}$. The materials were then treated with the Schiff reagent for $40 \mathrm{~min}$, in the dark, at room temperature. Afterwards, the materials were rinsed in three batches of sulfurous water $(5 \mathrm{~min}$ each) and in distilled water. The materials were gently squashed in a drop of $45 \%$ acetic acid, such that part of the sperm cells were extruded from the spermathecae while spermathecal gland fragments remained as whole-mounted structures with nondisrupted, whole nuclei. The cover slip was removed in liquid nitrogen, and the preparations were rapidly rinsed in $90 \%$ ethanol and air-dried. Next, the preparations were cleared in xylene for $15 \mathrm{~min}$ and mounted in natural Canada balsam $\left(n_{\mathrm{D}}=1.54\right)$.

All the staining and subsequent steps were performed in parallel for early-mated and old queen materials to minimize variations in the experimental conditions and reduce the possibility of systematic errors.

\subsection{Image analysis}

Nuclei chosen at random were analyzed using Carl Zeiss/Kontron equipment and Kontron KS400-3 software (Oberkochen, Munich, Germany). Various numbers of nuclei were analyzed depending on the operational facilities, which required non-overlapping images to be measured. The images were obtained with a Zeiss Axiophot 2 microscope equipped with a Neofluar 40/0.75 objective, optovar factor 2, 0.90 condenser, and a monochromatic filter of $\lambda=546 \mathrm{~nm}$. A $100-\mathrm{W}$ halogen illuminator, a voltage regulator for light intensity maintained constant at point 4 , filter wheels 1 and 2 rotated into position 100 (open position), and a luminous-filter diaphragm (transmitted light) at its maximal opening were used. The illumination conditions were held constant for all of the nuclei investigated. The images to be processed were transferred from the microscope to a Fujitsu/Siemens computer using a Zeiss AxioCam HRc color video camera. The threshold low $(L)$ and high $(H)$ levels were defined such that the nuclear images appeared with a green false color and were well separated from each other and from the background. In most cases, $L=20$ and $H=110-122$ gray values. Under the optical conditions used, $1 \mu \mathrm{m}$ corresponded to 12.4 pixels. The minimum area that could be measured in this apparatus corresponded to four pixels. The software provided quantitative information on the following: the nuclear area $\left(\mu \mathrm{m}^{2}\right)$, the mean gray value per nucleus (a value that was subsequently converted into optical density (OD) (=absorbances), the standard deviation of the total densitometric values per nucleus or the absorbance variability per nucleus (SDtd), and the entropy (the number of bits needed to store the densitometric values per nucleus image) (Kontron KS400, 1995). The Feulgen-DNA values in arbitrary units were calculated from the multiplication of the absorbances by the nuclear area (integrated $\mathrm{OD}=\mathrm{IOD}$ ).

Spermatozoa contained in the spermatheca and released by rupture of this organ were used as the control for Feulgen-DNA class $1 \mathrm{C}$ (haploidy).

\subsection{Statistics}

All calculations, including ANOVA, Mann-Whitney tests, histograms, and fitted line plots, were prepared with Minitab $12^{\mathrm{TM}}$ software (State College, PA, USA).

\section{RESULTS}

The images of the Feulgen-stained spermathecal glands of early-mated and both the one- and 1.5-year old queens revealed secretory cell nuclei that were much larger than the intima nuclei (Figure 1). Feulgen-DNA amounts, which are also higher in the secretory cell nuclei than in the intima nuclei, increased with age only for the 1.5-year old queens (Tables I and II). Morphological aspects suggestive of apoptotic cell death were not observed in these nuclei.

When considering frequency histograms plotted with the Feulgen-DNA values, polyploidy was easily revealed for both secretory and intima nucleus types of the spermathecal glands of early-mated and old queens of both origins (Figures 2 and 3). However, in old queens, one additional ploidy degree was detected (Figure 3). Regarding the secretory cell nuclei, while the $16 \mathrm{C}$ ploidy degree predominated in early-mated queens from both origins (Figures 2 and 3), the 


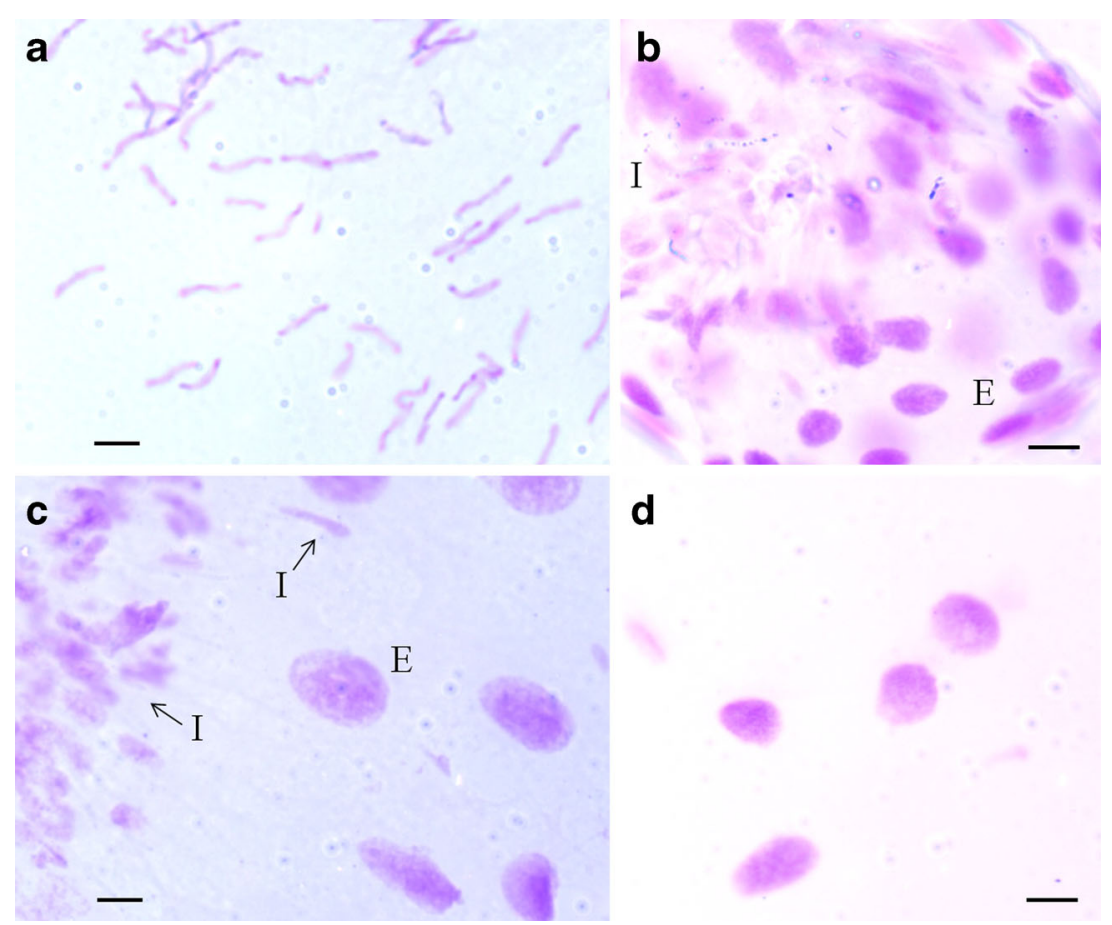

Figure 1. Feulgen-stained sperm cells stored in the spermatheca (a) and nuclei of the secretory (E) (b-d) and intima layer (I) (b, c) of whole-mounted spermathecal glands of early-mated (a-c) and aged (d) A. mellifera queens. Bars equal $10 \mu \mathrm{m}$.

$32 \mathrm{C}$ degree was predominant in the 1.5 -year old queens (Figure 3). A few nuclei with FeulgenDNA amounts corresponding to the $8 \mathrm{C}$ and $32 \mathrm{C}$ classes were present in early-mated and one-year old queens (Figure 2), and a few nuclei with Feulgen-DNA amounts corresponding to the $8 \mathrm{C}$, $16 \mathrm{C}$, and $64 \mathrm{C}$ classes were found in 1.5-year old queens (Figure 3).

In the intima layer of the spermathecal glands of one-year old queens, nuclei of the 4 $\mathrm{C}, 8 \mathrm{C}$, and even $<2 \mathrm{C}$ classes were also found, although the nuclei were predominantly of the $2 \mathrm{C}$ class in the early-mated queens (Figure 2). The $4 \mathrm{C}$ class nuclei were more frequent in the 1.5-year old queens than in the early-mated queens of the same origin; some nuclei were also found to belong to the $<2 \mathrm{C}$ class (Figure 3).

Changes in the SDtd and entropy parameters were found in the Feulgen-stained nuclei of the secretory cells and the intima of the spermathecal glands, indicating the onset of chromatin texture modifications with aging (Tables I and II). A decrease in SDtd in one-year old queens was found to affect only the secretory cells of the spermathecal glands, indicating a certain packing state unraveling of the chromatin in these cells (Table I). Regarding nuclear entropy in these queens, lower values were found in the secretory cells and intima (Table I), revealing a trend towards a more homogeneous distribution of the condensed chromatin at younger ages. The increase in the SDtd and entropy values in both nucleus types of the 1.5-year old queens, in comparison to early-mated queens, indicates an increase in chromatin packing states, accompanied by a heterogeneous distribution of the condensed chromatin areas, at this age (Table II).

When plotting the entropy versus the FeulgenDNA values, a different trend of entropy changes as a function of the increasing ploidy degrees was found for the nuclei of the secretory cells of aged queens compared with early-mated queens (Figure 4). While in early-mated queens 
Table I. Image densitometric and textural parameters of Feulgen-stained spermathecal gland nuclei of earlymated and one-year old A. mellifera queens (source-Faria Lemos, MG).

\begin{tabular}{|c|c|c|c|c|c|c|c|c|c|}
\hline \multirow[t]{2}{*}{ Parameters } & \multirow[t]{2}{*}{ Materials } & \multicolumn{4}{|c|}{ Early-mated queens } & \multicolumn{4}{|c|}{ Old queens } \\
\hline & & $X$ & $S$ & $\mathrm{Md}$ & $n$ & $X$ & $S$ & $\mathrm{Md}$ & $n$ \\
\hline \multirow{3}{*}{$\begin{array}{l}\text { Feulgen-DNA } \\
\text { values (A.U.) }\end{array}$} & Spermatozoa $^{\mathrm{a}}$ & 1.27 & 0.32 & 1.23 & 50 & - & - & - & - \\
\hline & SG intima & 4.34 & 2.27 & $3.98 \mathrm{a}$ & 61 & 3.15 & 1.50 & $2.64 b$ & 231 \\
\hline & SG secretory cells & 30.53 & 6.45 & $30.06 \mathrm{a}$ & 235 & 31.13 & 10.96 & $29.46 \mathrm{a}$ & 495 \\
\hline \multirow[t]{3}{*}{ SDtd } & Spermatozoa & 7.31 & 2.33 & 6.93 & 50 & - & - & - & - \\
\hline & SG intima & 5.61 & 2.48 & $5.09 \mathrm{a}$ & 61 & 5.27 & 2.21 & $4.91 \mathrm{a}$ & 231 \\
\hline & SG secretory cells & $13.19 \mathrm{~A}$ & 3.31 & 13.34 & 235 & $11.13 \mathrm{~B}$ & 3.35 & 10.92 & 495 \\
\hline \multirow[t]{3}{*}{ Nuclear entropy } & Spermatozoa & 4.56 & 0.44 & 4.56 & 50 & - & - & - & - \\
\hline & SG intima & $4.20 \mathrm{~A}$ & 0.55 & $4.21 \mathrm{a}$ & 61 & $4.12 \mathrm{~B}$ & 0.57 & $4.15 \mathrm{a}$ & 231 \\
\hline & SG secretory cells & $5.45 \mathrm{~A}$ & 0.36 & 5.51 & 235 & $5.22 \mathrm{~B}$ & 0.39 & 5.25 & 495 \\
\hline
\end{tabular}

Different letters (A, B) for $X$ values in the same line mean differences significant at $P_{0.05}$ (ANOVA); different letters (a, b) for Md values in the same line mean differences significant at $P_{0.05}$ (Mann-Whitney test)

A. $U$. arbitrary units, $M d$ median, $n$ number of nuclei counted, $S$ standard deviation, $S G$ spermathecal glands, $X$ arithmetic mean

${ }^{a} 1$ C DNA content control

and one-year old queens, there is a tendency for the entropy of the secretory cell nuclei to decrease with increasing ploidy degrees (due to a more homogeneous distribution of condensed chromatin packing states), in 1.5-year old queens, the high entropy values attained (due to a heterogeneous distribution of condensed chromatin packing states) are maintained in the

Table II. Image densitometric and textural parameters of Feulgen-stained spermathecal gland nuclei of earlymated and 1.5-year old $A$. mellifera queens (source-Ribeirão Preto, SP).

\begin{tabular}{|c|c|c|c|c|c|c|c|c|c|}
\hline \multirow[t]{2}{*}{ Parameters } & \multirow[t]{2}{*}{ Materials } & \multicolumn{4}{|c|}{ Early-mated queens } & \multicolumn{4}{|c|}{ Old queens } \\
\hline & & $X$ & $S$ & $\mathrm{Md}$ & $n$ & $X$ & $S$ & $\mathrm{Md}$ & $n$ \\
\hline \multirow{3}{*}{$\begin{array}{l}\text { Feulgen-DNA } \\
\text { values (A.U.) }\end{array}$} & Spermatozoa $^{\mathrm{a}}$ & $1.53 \mathrm{~A}$ & 0.41 & 1.41 & 133 & $1.45 \mathrm{~A}$ & 0.29 & 1.40 & 28 \\
\hline & SG intima & 5.87 & 4.48 & $3.81 \mathrm{a}$ & 35 & 6.49 & 3.85 & $5.06 \mathrm{a}$ & 70 \\
\hline & SG secretory cells & 30.28 & 9.59 & $29.55 a$ & 114 & 64.31 & 17.85 & $66.27 b$ & 152 \\
\hline \multirow[t]{3}{*}{ SDtd } & Spermatozoa & $5.32 \mathrm{~A}$ & 1.50 & 5.07 & 133 & $5.53 \mathrm{~A}$ & 1.60 & 5.19 & 28 \\
\hline & SG intima & 2.34 & 1.18 & $1.98 \mathrm{a}$ & 35 & 5.41 & 1.67 & $5.08 \mathrm{~b}$ & 70 \\
\hline & SG secretory cells & $5.16 \mathrm{~A}$ & 1.63 & 4.95 & 114 & $13.08 \mathrm{~B}$ & 2.56 & 12.85 & 152 \\
\hline \multirow[t]{3}{*}{ Nuclear entropy } & Spermatozoa & $4.14 \mathrm{~A}$ & 0.35 & 4.13 & 133 & $4.20 \mathrm{~A}$ & 0.37 & 4.20 & 28 \\
\hline & SG intima & $2.98 \mathrm{~A}$ & 0.65 & 2.95 & 35 & $4.26 \mathrm{~B}$ & 0.43 & 4.27 & 70 \\
\hline & SG secretory cells & $4.16 \mathrm{~A}$ & 0.43 & 4.20 & 114 & $5.54 \mathrm{~B}$ & 0.26 & 5.57 & 152 \\
\hline
\end{tabular}

Different letters (A, B) for $X$ values in the same line mean differences significant at $P_{0.05}$ (ANOVA); different letters (a, b) for Md values in the same line mean differences significant at $P_{0.05}$ (Mann-Whitney test)

A.U., arbitrary units, $M d$ median, $n$ number of nuclei counted, $S$ standard deviation, $S G$ spermathecal glands, $X$ arithmetic mean

${ }^{\mathrm{a}} 1 \mathrm{C}$ DNA content control 

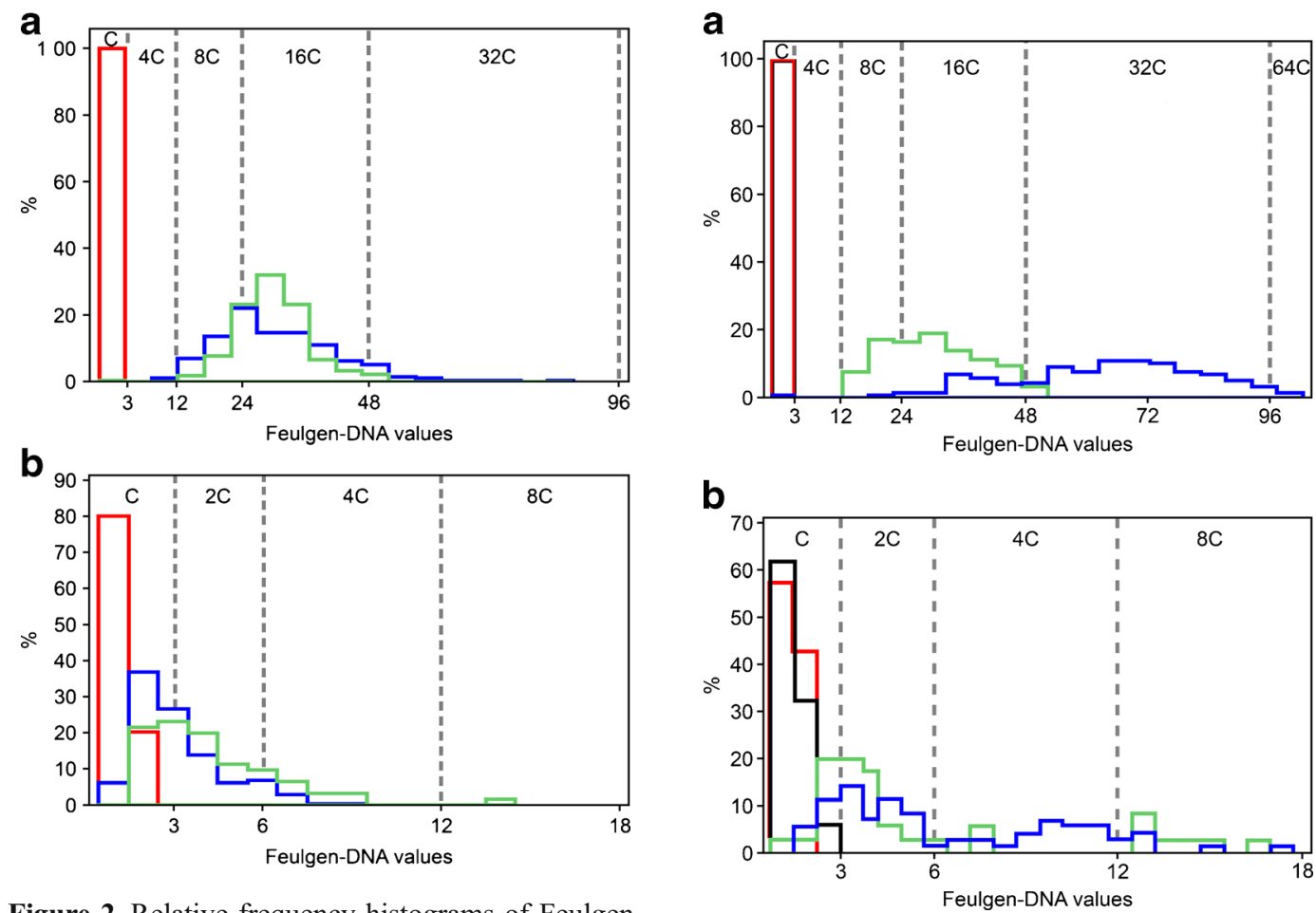

Figure 2. Relative frequency histograms of FeulgenDNA values in arbitrary units obtained for the secretory cells (a) and intima-layer nuclei (b) of early-mated (green) and one-year old (blue) A. mellifera queens. Sperm cell values (red) were used as the haploid (1 C DNA content) control. $X$ axis, Feulgen-DNA values in arbitrary units.

cell nuclei irrespective of their ploidy degrees (Figure 4). Regarding the intima nuclei, the entropy increased with ploidy increase in earlymated queens from Ribeirão Preto and Faria Lemos and in the one-year old queens. In the 1.5-year old queens, the same behavior that was observed for the secretory cell nuclei was observed for the intima nuclei (Figure 4).

\section{DISCUSSION}

Neither morphological aspects nor changes in the Feulgen-DNA values that suggest cell death were found in the secretory cells of the spermathecal glands of the honeybee queens up to 1.5 years in age. No DNA fragmentation was evident with the TUNEL assay in these

Figure 3. Relative frequency histograms of FeulgenDNA values in arbitrary units obtained for the secretory cells (a) and intima-layer nuclei (b) of early-mated (green) and 1.5-year old (blue) A. mellifera queens. Sperm cell values (red-earlymated queens; black - aged queens) were used as the haploid (1 C DNA content) control. $X$ axis, Feulgen-DNA values in arbitrary units.

cells (data not shown). In addition, the low Feulgen-DNA values $(<2 \mathrm{C}$ class) that were detected for part of the intima nuclear population could not be attributed to cell death due to aging, as they occurred not only in the one- and 1.5-year old queens, but also in the early-mated queens. This result may indicate the occurrence of DNA loss due to a constitutively decreased resistance of certain unpacked DNA segments to the acid hydrolysis associated with the Feulgen reaction, leading to the solubilization of apurinic acid in the chromatin of the intima nuclei (Mello 1979; Felisbino et al. 2011). Therefore, cell death cannot be associated with a presumably changing cellular physiology in 
a

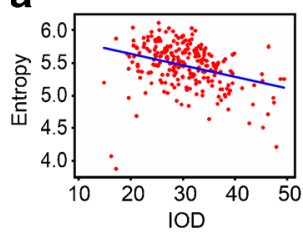

e

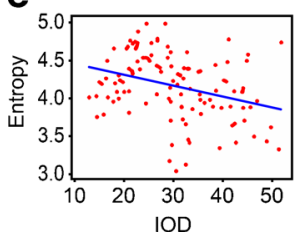

b

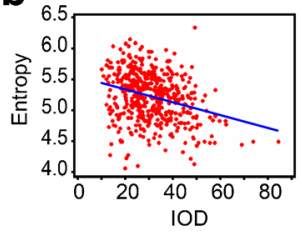

f

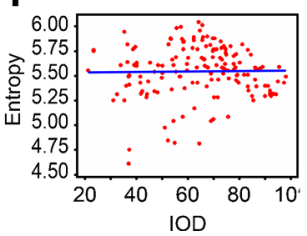

C

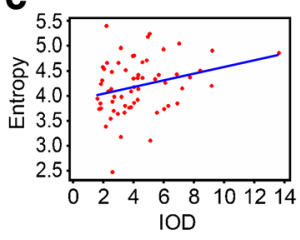

9

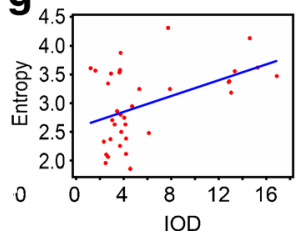

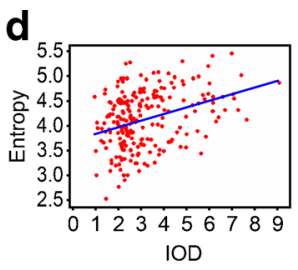

h

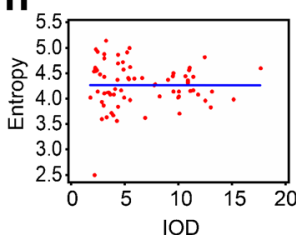

Figure 4. Fitted line plots showing the relationship between nuclear entropy ( $Y$ axis) and Feulgen-DNA values in arbitrary units ( $X$ axis) for the secretory cells $(\mathbf{a}, \mathbf{b}, \mathbf{e}, \mathbf{f})$ and intima-layer nuclei $(\mathbf{c}, \mathbf{d}, \mathbf{g}, \mathbf{h})$ of early-mated $(\mathbf{a}, \mathbf{c}, \mathbf{e}, \mathbf{g})$ and one- (b, d) and 1.5-year old (f, h) A. mellifera queens.

the spermathecal glands due to aging, with consequences to their secretory activities at least up to the age of 1.5 years.

The general phenomenon of polyploidization found in both spermathecal gland nucleus types of the A. mellifera queens is not unusual for bees, although it is generally mostly detected within larval organs such as the silk glands and Malpighian tubules of female castes and drones of this species (Mello and Takahashi 1971). Unpublished data by Falco (1995) describes the use of scanning microspectrophotometry studies that also identified DNA levels in the spermathecal glands of $A$. mellifera, which are indicative of polyploidy. However, the additional ploidy degree found in the spermathecal glands with increased age could have been triggered as a compensatory cellular mechanism for coping with the stress of aging due to the increased reactive oxygen species and other genotoxic agents over time (Jones and Ravid 2004; Anatskaya and Vinogradov 2010). In addition, along with this polyploidization due to aging in the 1.5 -year old honeybee queen, a selective suppression of gene expression could also occur, leading to a decline in certain functions.

Differential transcript expression as a result of an increase in ploidy, meaning that a selected group of genes may not be expressed proportionally to the DNA content, has been reported for several different organisms, including isogenic yeast, Arabidopsis thaliana, and mice (aortic vascular smooth muscle and liver cells) (Galitski et al. 1999; Lee and Chen 2001; Jones and Ravid 2004; Ghiraldini et al. 2014). However, this phenomenon has not yet been reported in insects. According to Hieter and Griffiths (1999), the findings of Galitski et al. (1999) of a ploidy paradox for isogenic yeast, in which a small subset of genes is dramatically repressed or induced in response to increased ploidy, "provide definitive evidence for a ploidy-driven mechanism of gene regulation that may be important in a variety of biological states."

In the aortic vascular smooth muscle of rats and mice, for example, where polyploidy is a biomarker for aging, the augmented DNA content is accompanied by a selective $\geq 2$-fold suppression of the expression of certain genes, including those related to matrix proteins, growth factors, and inflammation-associated transcripts (Jones and Ravid 2004). In mouse liver cells, where increased polyploidization is also a well-known characteristic of aging (Gupta 2000; Anatskaya and Vinogradov 2010; Moraes et al. 2007; Ghiraldini et al. 2012), 122 genes are up-regulated and 77 genes are down-regulated due to aging (Ghiraldini et al. 2014). Among the downregulated genes with $\mathrm{a} \geq 2$-fold change, several 
genes were found to be related to signal transduction, transcription, post-translational modifications, and inflammatory responses, and at least four genes were found to be related to chromatin structure and dynamics (Ghiraldini et al. 2014).

A similar effect may occur in the spermathecal glands of the honeybee queens. In addition, the increased polyploidization in these glands at the 1.5 years of age is accompanied by an increase in the chromatin packing state and its heterogeneous distribution in the cell nuclei. A change in chromatin condensation and spatial distribution of high and medium density chromatin components has also been reported with image analysis procedures to be associated with the aging process in the housefly (Panno and Nair 1984). Considering that chromatin remodeling may reflect altered gene modulation (Dejligbjerg et al. 2008; Felisbino et al. 2011; Ghiraldini et al. 2012, 2014), the functional properties of the spermathecal glands of the honeybee queens would certainly be affected by aging. It could be hypothesized that by promoting a protective mechanism against increased oxidative stress in the cells, other cellular functions may be impaired by elevated polyploidization (Anatskaya and Vinogradov 2010), interfering, for instance, with the production of secretions required for the efficiency of sperm-cell preservation in the spermatheca. It has been reported that a decreasing quality of sperm cells determined by their slower movements and different movement patterns, could be indicative of decreased spermatozoal viability in the spermatheca of two-year old queens in comparison to the sperm cells of one-year old queens (Al-Lawati et al. 2009). As proteins and other elements of the spermathecal fluid ensure sperm survival (Baer et al. 2009; den Boer et al. 2009), it is possible that the nuclear changes that occur in the spermathecal glands with aging affect their cellular physiology as suppliers of proteins and microenvironmental elements discharged in the spermatheca, consequently having an impact on the viability of the stored sperm cells.

\section{ACKNOWLEDGMENTS}

The authors are indebted to Dr. Lionel Segui Gonçalves, MSc. Daiana Almeida de Souza (University of São Paulo, Ribeirão Preto, Brazil), and Dr. Osmar Malaspina (State University of São Paulo, Rio Claro, Brazil) for generously providing queen honeybees from the São Paulo State and to the São Paulo State Research Foundation (FAPESP), the Brazilian R \& D Council $(\mathrm{CNPq})$, and the Coordination of Improvement of Higher Education Personnel (CAPES) for the financial support. This study was part of a thematic project supported by FAPESP (grant no. 2010/50015-6).

\section{OPEN ACCESS}

This article is distributed under the terms of the Creative Commons Attribution License which permits any use, distribution, and reproduction in any medium, provided the original author(s) and the source are credited.

Contenu en ADN-Feulgen et organisation de la chromatine dans les glandes spermathécales des reines de l'abeille, Apis mellifera (Hymenoptera, Apoidea) au cours du vieillissement

Reine / polyploïdie / vieillissement / ADN / coloration de Feulgen / fonction cellulaire

Feulgen DNA-Gehalt und Chromatinorganisation in Spermathekaldrüsen von Apis mellifera (Hymenoptera, Apoidea) Königinnen in Bezug zum Altern

Königin / Spermathekaldrüsen / Polyploidie / Chromatin / Altern

\section{REFERENCES}

Al-Lawati, H., Kamp, G., Bienefeld, K. (2009) Characteristics of the spermathecal contents of old and young honeybee queens. J. Insect Physiol. 55, $117-122$

Anatskaya, O.V., Vinogradov, A.E. (2010) Somatic polyploidy promotes cell function under stress and energy depletion: evidence from tissue-specific mammal transcriptome. Funct. Integr. Genomics 10, 433-446

Baer, B., Eubel, H., Taylor, N.L., O’Toole, N., Millar, A.H. (2009) Insights into female sperm storage from the spermathecal fluid proteome of the honeybee Apis mellifera. Genome Biol. 10, R67 
Butler, C.G. (1954) The world of the honeybee. Willmer Brothers \& Co. Ltd., London

Camargo, J.M.F., Mello, M.L.S. (1970) Anatomy and histology of the genital tract, spermatheca, spermathecal duct and glands of Apis mellifica queens (Hymenoptera: Apidae). Apidologie 1, 351-373

Dallai, R. (1975) Fine structure of the spermatheca of Apis mellifera. J. Insect Physiol. 21, 89-109

Dejligbjerg, M., Grauslund, M., Litman, T., Collins, L., Qian, X., Jeffers, M., Lichenstein, H., Jensen, P.B., Sehested, M. (2008) Differential effects of class I isoform histone deacetylase depletion and enzymatic inhibition by belinostat or valproic acid in HeLa cells. Mol. Cancer 7, 70

den Boer, S.P.A., Boomsma, J.J., Baer, B. (2009) Honey bee males and queens use glandular secretions to enhance sperm viability before and after storage. J. Insect Physiol. 55, 538-543

Falco J.R.P. (1995) Alterações celulares pós-fecundação e com o envelhecimento em glândulas da espermateca de rainhas de Apis mellifera (Hymenoptera, Apoidea). Masters' Dissertation, Campinas: University of Campinas

Felisbino, M.B., Tamashiro, W.M.S.C., Mello, M.L.S. (2011) Chromatin remodeling, cell proliferation and cell death in valproic acid-treated HeLa cells. PLoS ONE 6, e29144

Galitski, T., Saldanha, A.J., Styles, C.A., Lander, E.S., Fink, G.R. (1999) Ploidy regulation of gene expression. Science 285, 251-254

Ghiraldini, F.G., Silva, I.S., Mello, M.L.S. (2012) Polyploidy and chromatin remodeling in hepatocytes from insulin-dependent diabetic and normoglycemic aged mice. Cytometry A 81, 755-764

Ghiraldini, F.G., Silveira, A.B., Kleinjan, D.A., Gilbert, N., Mello, M.L.S. (2014) Genomic profiling of type1 adult diabetic and aged normoglycemic mouse liver. BMC Endocrine Dis. (in press).

Gupta, S. (2000) Hepatic polyploidy and liver growth control. Semin. Cancer Biol. 10, 161-171

Guzman-Novoa, E., Page, R.E., Prieto-Merlos, D. (1998) Queen introduction, acceptance, and survival in honey bee (Hymenoptera: Apidae) colonies of a tropical, Africanized region. J. Econ. Entomol. 91, 1290-1294

Hieter, P., Griffiths, T. (1999) Polyploidy-more is more or less. Science $\mathbf{2 8 5}, 210-211$

Jones, M.R., Ravid, K. (2004) Vascular smooth muscle polyploidization as a biomarker for aging and its impact on differential gene expression. J. Biol. Chem. 279, 5306-5313
Klenk, M., Koeniger, G., Koeniger, N., Fasold, H. (2004) Proteins in spermathecal gland secretion and spermathecal fluid and the properties of a $29 \mathrm{kDa}$ protein in queens of Apis mellifera. Apidologie 35, 371-381

Kontron Elektronic Imaging System KS400 (1995) User's Guide, vol. 1. Kontron Elektronic GmbH, Eching/Munich

Laidlaw Jr., H.H. (1944) Artificial insemination of the queen bee (Apis mellifera L.). Morphological basis and results. J. Morphol. 74, 429-465

Lee, H.S., Chen, Z.J. (2001) Protein-coding genes are epigenetically regulated in Arabidopsis polyploids. Proc. Natl. Acad. Sci. U. S. A. 98, 6753-6758

Mampumbu, A.R., Vidal, B.C., Mello, M.L.S. (2004) Feulgen staining in Malpighian tubules of meliponid bees: a methodological contribution. Braz. J. Morphol. Sci. 21, 31-33

Mello, M.L.S. (1979) Patterns of lability towards acid hydrolysis in heterochromatin and euchromatin of Triatoma infestans Klug. Cell. Mol. Biol. 24, 1-16

Mello, M.L.S. (1997) Cytochemistry of DNA, RNA and nuclear proteins. Braz. J. Genet. (Genet. Mol. Biol.) 20, 257-264

Mello, M.L.S., Raymundo, H.H. (1977) Change with age of Feulgen-DNA values in the blood-sucking insect, Triatoma infestans Klug. Histochem. Cell Biol. 54, 219-223

Mello, M.L.S., Takahashi, C.S. (1971) DNA content and nuclear volume in larval organs of Apis mellifera. J. Apic. Res. 10, 125-132

Moraes, A.S., Guaraldo, A.M.A., Mello, M.L.S. (2007) Chromatin supraorganization and extensibility in mouse hepatocytes with development and aging. Cytometry A 71, 28-37

Panno, J.P., Nair, K.K. (1984) Chromatin condensation in the aging housefly. Exp. Gerontol. 19, 63-72

Rodrigues, H.F., Souza, T.A., Ghiraldini, F.G., Mello, M.L.S., Moraes, A.S. (2014) Increased age is associated with epigenetic and structural changes in chromatin from neuronal nuclei. J. Cell. Biochem. 115, 659-665

Szabo, T.I., Heikel, D.T. (1987) Number of spermatozoa in spermathecae in queens aged 0 to 3 years reared in Beaverlodge, Alberta. J. Apic. Res. 26, 79-82

Verma, L.R. (1974) Honeybee spermatozoa and their survival in the queen's spermatheca. Bee World 55, 53-61

Weirich, F.G., Collins, M.A., Williams, P.V. (2002) Antioxidant enzymes in the honeybee Apis mellifera. Apidologie 33, 3-14 